\title{
INDUSTRIAL ACTIVITIES IN MUREŞ COUNTY (PART II)
}

\author{
George-Bogdan TOFAN* \\ „Vasile Goldiş” Western University of Arad, Faculty of Economic Sciences, Engineering and Informatics, Departament of \\ Engineering and Informatics, Baia Mare Branch, 5 Culturii Street, Romania \\ e-mail: bogdan.tofan@uvvg.ro
}

\section{Adrian NIȚĂ}

„Babeș-Bolyai” University, Faculty of Geography, Gheorgheni Branch, Csiki Garden, Romania e-mail: nitaadrian@ hotmail.com

\begin{abstract}
In Mureş County, year 2015, the secondary sector comprised a total number of 42,427 workers, fifth place of the 10 Transylvanian counties $(11.2 \%$ of the 377,517 employees). Thusly, the values of industrial production were structured as follows: light industry $(18.3 \%, 7,763$ employees), wood processing industry $(17.7 \%, 7,513)$, food industry $(16.8 \%, 7,129)$, machine industry $(16.5 \%, 6,989)$, chemical, cellulose and paper industry $(8.8 \%, 3,739)$, construction material industry $(7 \%, 3,003)$, extractive industry $(6.2 \%, 2,661)$, other industrial branches $(4 \%, 1,662)$, electricity industry $(3.3 \%, 1,398)$, and metallurgical industry $(1.4 \%, 570)$.
\end{abstract}

Key words: methane gas, secondary sector, light industry

$$
* \quad * \quad * \quad * \quad * \quad *
$$

\section{INTRODUCTION}

The current scientific endeavour is a continuation of the 2018 study regarding industrial activity in Mureş County, published in the Annals of the University of Oradea, Geography Series, 28(1): 36-53. Therefore, the aim is to emphasize several other aspects of industry in Mureș, with a new cartographic depiction of the transport network and the active population distribution, generally trying to avoid reshuffling previously researched issues. This paper intends to create an inventory of the industrial activities that take place in Mureș County and, following the analysis of their origin and evolution, to identify several development directions, taking into account the principles of industrial localisation. The study aims to be a useful instrument for the local government, which can then develop strategies to attract investments according to the industrial branches most suitable for the county. The basic unit for industry analysis is the factory, which manufactures a product with the help of technological machinery and employs a labour force characterised by number and education level.

The clustering of enterprises into industrial branches is essential, as each industrial branch has a different approach when it comes to the origin and acquisition of resources (raw materials), energy, work force and its training, and, last but not least, product distribution. These requirements influence 
the principles of industrial organisation, the enterprises being located based on the required resources, type and quantity of energy used, outlet market location and the location of the component and spare parts providers. Locations frequently do not meet the required standards and enterprises select them based on the most advantageous financial conditions or focusing on industrial park type agglomerations. The short period between 1945-1948 was one of great complexity in terms of socialeconomic and political conditions, being an ambiguous transition period as Romania was under foreign ocuppation and forced to yield to pro-Soviet interests and reforms. On $11^{\text {th }}$ June 1948, the nationalisation of the main means of production began, mainly all industrial units with more than 50 employees, which became state property. The smaller units, with less than 50 employees, were transformed into local cooperative units, some eventually becoming middle or large state enterprises. Following said measures, the industry became a centralised and stepwise activity, whose evolution was to be directed and controlled by development plans (the first two years included annual plans, followed by five year plans, which also imposed development directions and clear objectives for their completion).

The old industrial plants were upgraded and expanded, alongside with the creation of new industries. Forced urbanisation therefore became the norm and a massive rural exodus took place, which led to the considerable depopulation of rural areas, with severe long term effects. This led to the establishment of the first chemical industry colossi of Mures County, Târnăveni Chemical Plant and Târgu-Mureș Nitrogen Fertilizer Plant, which required tremendous resources and energy to run. Two high capacity power plants were constructed for this very purpose, one in Fântânele and one in Iernut, which burned gas from the gas domes of the Transylvanian Plateau.

Other large enterprises emerged afterwards, in the siderurgical industry (Nicovala Sighişoara), construction materials (Sighișoara Ceramic Products Enterprise; Târgu-Mureș Constructions-Assembly Plant; Sighişoara Glass and Tile Enterprise; Ardeleana and Hercules Târnăveni), as well as in several industrial sectors located primarily in the county capital, such as: machinery (Metalotehnica; Light Industry Machinery Enterprise; Electromureș; Auto Repair Works), wood processing (Wood Mill), textiles (Silk Weaving Mill, „Mureșul”, Leather and Gloves Factory) and food (Sugar Factory, Mill, Bakery and Pasta Enterprise, Vegetables and Fruit Enterprise, Meat and Milk Enterprise, Vinalcool, Zahărul Luduş, etc).

The industry was mostly extensive in nature and therefore required a large workforce. Thusly, Romania became a massive energy consumer, with an ever decreasing capacity to provide food for its population. This contributed to the food and energy shortages of the 1980s, which impacted the populace first and foremost. These massive industrial investments required external loans. After 1990, as the economy transitioned to a market phenomenon, all industries suferred massive restructurings, complex and difficult privatizations, creating social problems and massive layoffs. The noncompetitive sectors became even less competitive after 1990. The system of commercial and autonomous companies proved unresponsive to the principles of consumption economy. Moreover, with the extinction of the Council for Mutual Economic Assistance, which included the former socialist states, Romania lost an important outlet market, as well as its Third World partners (the Arab countries). The massive privatisations that occured after 1997 and 2000 diminished the economic importance of the state, phenomenon further exacerbated by the insidious effect of intermediaries, at production level, as well as at distribution level (the „leech” company system). The current situation proves that most enterprises have been illicitly privatised, while many investors proved to be disloyal partners. In the end, this fact contributed to the dissolution of a massive part of production and therefore to a stringent need for job reconversion, a problem which has not been settled to this very day.

\section{METHODOLOGICAL ASPECTS}

We must emphasize that this scientific endeavour implied considerable research, especially the activity profiles of all current and former firms that had emerged after 1990, thus employing 
the historical method. Of great use were the documents provided by the Mureș Commerce and Industry Chamber, which devised ,lists and rankings” based on the four economic sectors, a methodological aspect integrated in the synthesis and analysis methods.

Several other studies were consulted, which helped us broaden our understanding of some important issues (Claval, 1974; Pop, 1972, 1996, 2007, 2012; Bailly and Béguin, 1982, 2001; Bailly, 1991; Max, 1991; Şoneriu and Mac, 1973; Harries and Norris, 1986; Nimigeanu, 1996; Carles, 1998; Păcurar, 2006; Barnes, 2009; Pop and Mârza, 2012; Cocean et al., 2013; Tofan, 2014; Bailly et al., 2017; Tofan and Niță, 2018), taking into account three fundamental principles: spatiality-causality-integration. All of these were acked by the information from the general urban plans and development strategies of the 102 smaller administrative-territorial units, the most used method being that of comparison.

We also utilized the statistical data provided by the Mureș County Department of Statistics, as well as the National Institute of Statistics, through its TEMPO-Online data base, the Work Force section, Employees subsection, number of employees at the end of each year, divided by industrial activities. Processing said data in order to emphasize the quantitative aspects of the phenomena and processes under scrutiny was done using statistical-mathematic techniques. Above all, lies field research, which enabled us to fully grasp the entire analysed territory, with cartographic representations, addended by information from websites and local media (the direct and indirect observation methods). Starting from the fundamental principles, by employing the methods of observation, analysis and synthesis (Herman and Benchiș, 2017; Herman et al., 2017; Ilieş et al., 2017), we identified the phenomena that led to the current location of industrial activities, while the deductive method helped us identify possible locations for future industrial development. For the most reader friendly graphical representation of information, we used the cartographic method (Baias et al., 2010; Herman et al., 2016; Ilieș et al., 2016; Romocea et al., 2018), superimposing our findings and demarcating the spatial units by contextual differences. Despite the fact that the total number of current industrial activities across the county were mentioned, there is a possibility that some may disappear, due to bankruptcy (Nimigeanu, 1996, p. 7). Difficulties arose due to the lack of quantitative information regarding supply, production and market, deemed classified by companies, which would have allowed for a better analysis of the infrastructure needed for the interlinking of the three main types of activities in an enterprise.

\section{THE EXTRACTIVE INDUSTRY}

The extractive industry is characterised by source location; in turn, it conditions the nearby location of mineral resource processing units. The vast majority of processing activities involve ore cleaning and sorting, which is why the transport of raw materials, together with the unusable halvus, must be avoided, to decrease costs. The existence of extractive centers and transport mainlines enables the insertion of units that consume a tremendous amount of energy from natural gas, which is less polluting than coal, but less efficient, most being metallurgical or chemical plants. Nonmetal resources also comprise construction materials, such as andesites with pyroxenes from the Mureș Defile (Meștera-Ciobotani) and Sovata (Ilieși), used primarily for road and railway constructions. Until 1995, Meștera quarry was state-owned. It was later purchased by S. C. Hamerock S. A. from Miercurea-Ciuc, which then merged with Lafarge Agregate Betoane. In 2004, the andesite quarry was acquired by Hodaco Prodcompex LLC.

It lies on the right bank of the Mureș River, with a surface area of around 12,000 square meters. Between the 1970s and 1997, there was a 6 hectare quarry operational in the Mermezeu Valley. Hodaco Prodcomex LLC of Stânceni obtained a licence in 2004 to continue andesite exploitation for a period of 14 years, which is roughly the same period for which the reserves are certified. In 2013, the licence for Mermezeu Quarry was awarded to Andezitul Stânceni LLC, headquartered in Târgu-Mureş, its surface area reaching 20,000 square meters. One of the major problems plaguing the two quarries is related to their uncertain judicial situation, since 
there has been no environmental permit issued. It is widely known that they are located in the Upper Mureș Defile Natural Park (natural protected area of national interest) and the exploitations require first and foremost an environmental impact study by the ministry. The rocks are used as they are, sorted solely as aggregates, and therefore special processing is not needed. However, the large reserves and the ever increasing demand for such materials nationwide requires the modernisation of the railway system, which is the main mode of land transport for heavy goods, by increasing speed on already electrified lines (main railway 4) and electrifying and overhauling the Deda-Războieni railway line.

\section{INDUSTRY OF ELECTRICAL ENERGY}

In 2013, Romgaz took control of the powerplant from Electrocentrale București, Electrocentrale Mureș Branch. The powerplant's output is limited to 39.5\% due to the high costs of natural gas and the prominence of hydroelectrical power and coal based energy. In order to reduce fuel consumption as well as to quell air pollution (especially nitrogen monoxide emissions), in the summer of 2018, the management made several investments to the plant's output, changing the technology for producing electricity by using the combined gas-steam cycle (classical and gas turbines). This improvement will become operational in 2020, with a total power of $430 \mathrm{MW}$.

The high installed capacity of the county and the flexibility of the energy production enables the development of high energy consuming industrial sectors. The Iernut powerplant can therefore function as a base unit, while the hydroelectric unit of Răstolița and the solar parks can deal with the energy spikes. However, the two main energy producers, Romgaz and Hidroelectrica, alongside Transelectrica, the manager of the National Energy System (NES), must update and reconfigure the connection network between the production units. The manufacturing of aluminum is a frequently given as an example of a high energy consumption sector, the plants being located mostly in energyintensive regions, as energy can rarely be transported without losses along the way. In most situations, bauxite (the required mineral for aluminum) is excavated across the globe, shipped in large quantities by transoceanic tankers to countries producing cheap energy, processed in ports in the form of alumina (such as Tulcea) and then transported by rail to aluminum plants. The fact that Mureș County is crossed by the main railways nr. 3 and 4 is therefore a considerable advantage.

\section{METALLURGY INDUSTRY AND MACHINES ENGINEERING}

The main phenomenon that caused the fall of the metallurgical and machinery industries was a lack of understanding of the mechanisms governing the market economy: most companies focused on production and distribution, without investing in scientific research, crucial in a competing market.

Before 1989, the state and society as whole managed scientific research, and the industrial units benefitted freely from it, while the county did not have a strong, traditional university and technological center, which could prepare future researchers. This phenomenon, under the new economic conditions, left most companies exposed. Lack of know-how regarding supply and outlet-markets exacerbated the problem, as it remained in the hands of the government, leading to uncertainty in terms of decisionmaking and loss mitigation. Contradictory information regarding development projects allowed neither the identification of sectors whose products could benefit from higher demand, nor the identification of development opportunities of new industrial branches. Beyond the necessity to invest in research and workforce training, the metallurgical and machinery industries are dependent on supply and sales. The faster and safer these processes are, the lower the product costs are; therefore, their vast majority will tend to concentrate in locations with easy access to fast transport and communications, such as highways, modernised railways, and airports. This clustering is further strengthened by the fact that machine building companies function better in industrial agglomerations, where they can easily trade with the elements required for complex product development and where they can put the already available infrastructure and services to good use. 


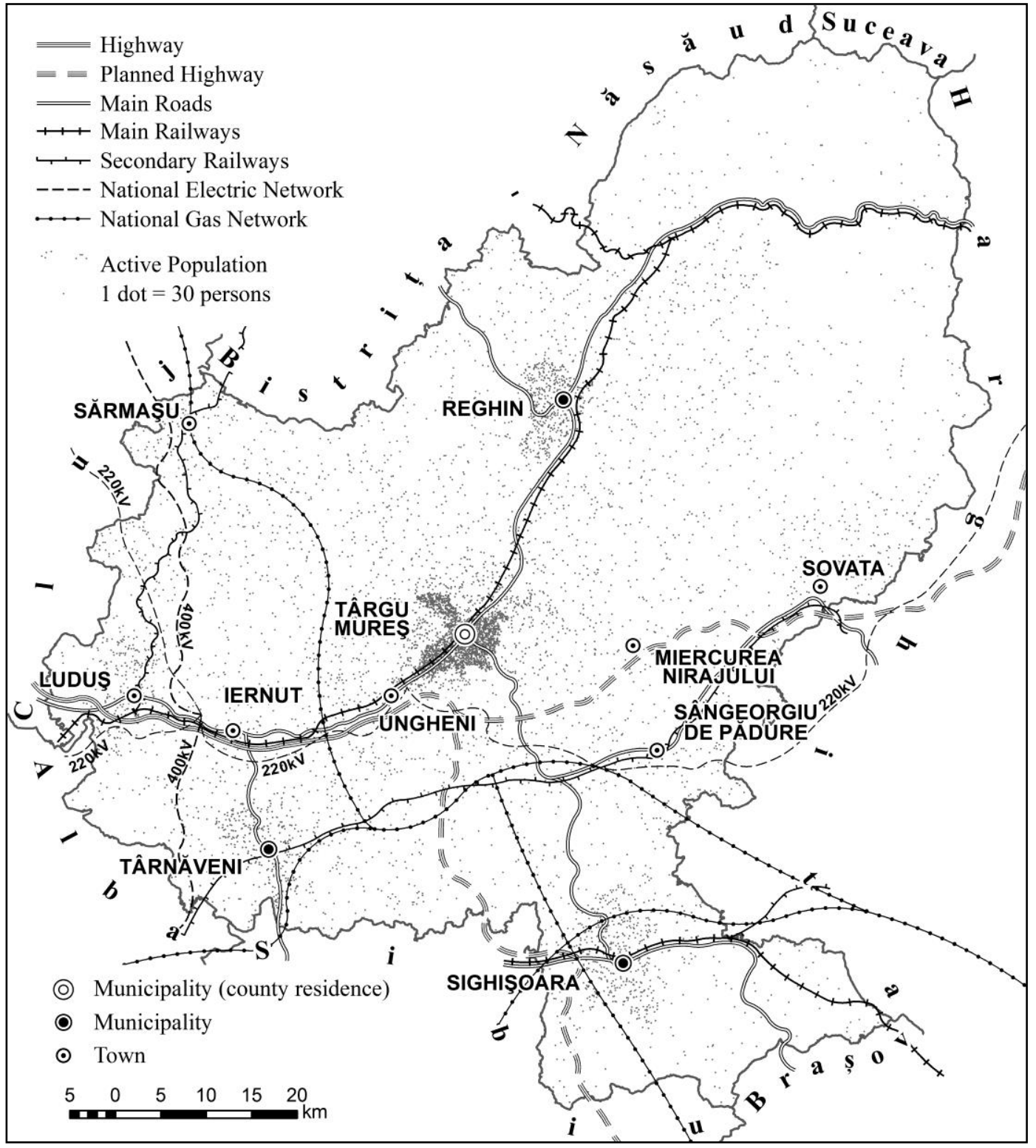

Figure 1. Main transport network and repartition of active population in Mureș County

\section{CHEMICAL AND PAPER INDUSTRY}

The largest chemical industrial plants are located in the vicinity of methane gas and salt deposits, on major circulation routes, mainly railways (the vast majority of products, bought in bulk and extremely heavy, are shipped by rail). Exports mainly pass through the distant Black Sea ports, which means that the lack of proper railway connections may critically hamper trading.

The medicine and cosmetics industries are the main engine and source of investments in research; therefore, drug and cosmetic companies will most likely locate near the educational, medical and pharmaceutical nexus of the county. 


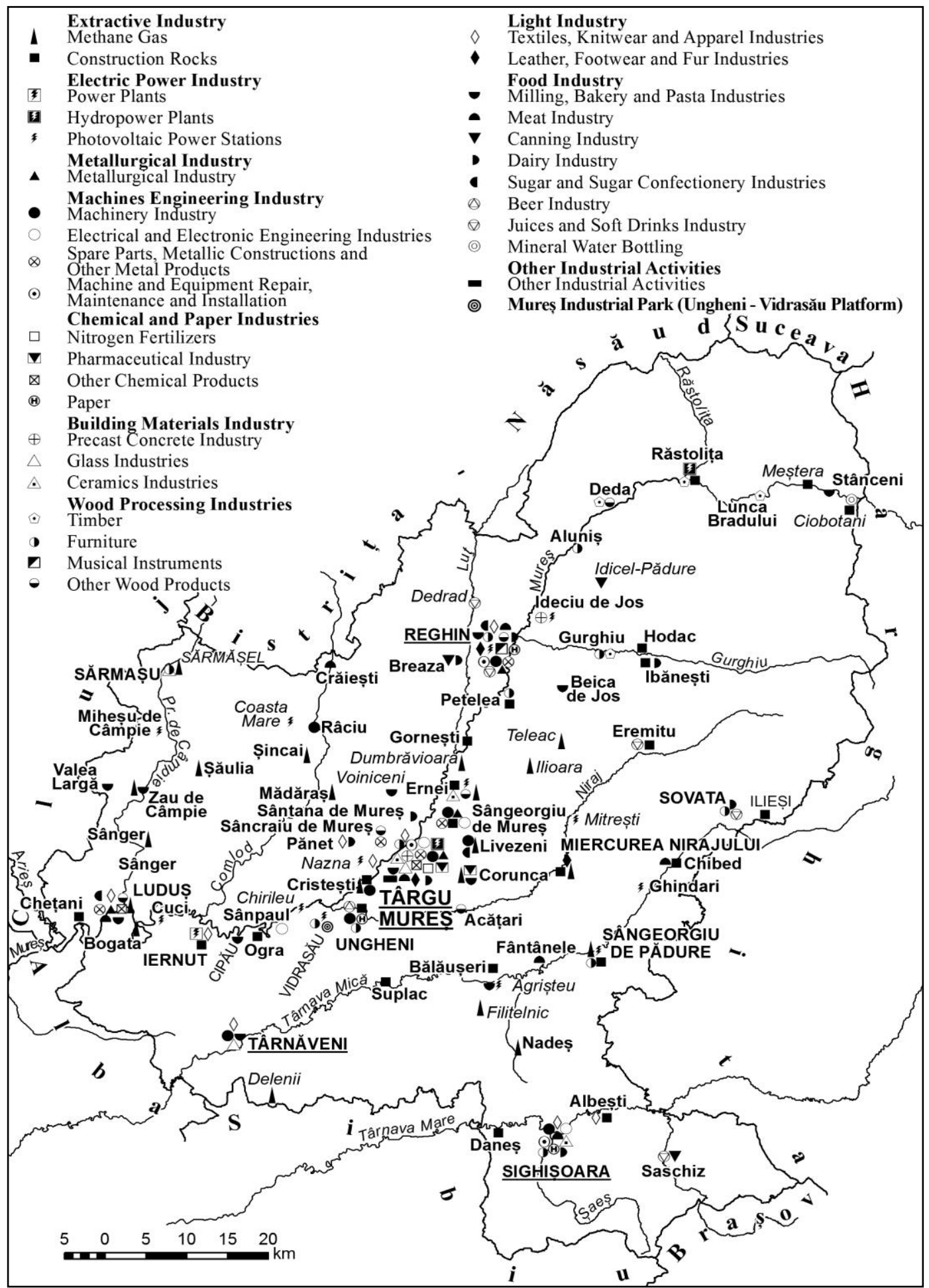

Figure 2. The industrial sectors and subsectors of Mureş County, 2017

(Source: G. B. Tofan \& A. Niță, 2018, p. 41) 


\section{CONSTRUCTION MATERIALS AND HANDICRAFT}

Suppliers of construction materials are generally concentrated close to their necessary resources, their markets, as well as to the available workforce. Despite the fact that a fast connection between supply, production and sales is important, the units comprising this sector have the advantage of product imperishability and are thus able to create caches; therefore, the less expensive locations, situated far from industrial clusters and main transport routes, are extremely suitable for such units, especially if a source of raw material is nearby.

\section{LIGHT INDUSTRY}

Light industry companies utilize light equipment, fewer raw materials, while the resulting products are easily shipped. The main location criterium is the availability of cheap labour, especially when one takes into account the fact that workforce training is effortless. Raising land prices in large cities and close to transport routes will eventually force these companies to relocate to the adjacent rural areas, frequently containing a young labour force.

\section{FOOD INDUSTRY}

Resource and product perishability is the main element influencing the location of food industry. The existence of cheap labour is an additional criterium. Therefore, their location is either at the source, or in areas with easy access to transport infrastructure, for a fast connection with distributors and consumers. Frequent locations are smaller cities and towns, halfway between the source and the main transport routes. These are locations with an infrastructure superior to communes and a relatively well-educated labour force.

\section{CONCLUSIONS}

At the end of this scientific endeavour, we would like to draw some conclusions on the topic at hand:

- the activities of the secondary sector in Mureş are part of the Transylvanian industrial region, of great complexity, represented by almost all industries, from natural resource extraction all the way to industrial processing, with its subsectors;

- in terms of the industrial production value of the county, the light industry holds the number one spot with $18.3 \%$, while metallurgy is last, with only $1.4 \%$;

- Mureş County has two main industrial areas: one on the middle section of Mureş, with high industrial concentrations in Târgu-Mureş (metallurgy, machinery, chemical industry, wood processing, ligh and food industries), followed by other centres such as: Reghin (metallurgy, machinery, furniture and musical instruments, textiles, shoes, beverages etc); Ungheni (construction materials, machinery, furniture, beer etc), Iernut (construction materials, energy and textiles)and Luduş (sugar), while the second lies on the Târnave (Târnăveni, Sighişoara, Sângeorgiu de Pădure), with a concentration of industries producing machinery, electronics, glass and ceramics, furniture, textiles, dairy products etc;

- positioned in the metropolitan area of the county capital, the commune of Sângeorgiu de Mureş is the most industrialized rural area (metallurgy, machinery, other metal products etc), there are also a series of communes specialized in food industries: Agrişteu, Voiniceni, ValeaLargă (bakery and pastry), Crăieşti, Fântânele (meat), Breaza, Brâncoveneşti, Saschiz (cans), Ibăneşti, Pănet, Sântana de Mureş, Breaza (dairy), Batoş (beverages), Stânceni (mineral water bottling);

- the most important industrial units are the following: Iernut Powerplant (energy), Plasmaterm (metallurgy), Maviprod \& Irum (machinery), Electromureş, Hirschmann Automotive (electrotechnics and electronics), Azomureş (chemical fertilizers), Gedeon Richter, Bioeel, Sandoz (medicine and pharmaceuticals), Romchim (other chemical products), Gecsat (glass), Siceram (ceramics), Mobex, MobilaDalin, MobilăSovata, Artemob, Kastamonu (furniture), Hora, Gliga (musical instruments), Textor, Larom, Târnava (textile industry), 
Manpel, Alpina Shoe Production (shoe and leather), Eldi, TimKo Brut (bakery and pastry), Primacom, OpreaAvicom, Egan Prod (meat); AgroSprint (can industry), Hocland, Mirdatod Prod, Therezia, Indlacto (cheese), Tereos (sugar), Neumarkt (beer industry), NaturAgrofar (beverages), Romaqua Stânceni (mineral water bottling) etc.

- the most significant changes took place in Târnăveni (Bicapa, Carbid Fox, and Cars), which led to depopulation and poverty;

- the existence of single industrial park, at Ungheni-Vidrasău, currently hosting with 18 firms and 1,700 employees (Tofan \& Niţă, 2018, p. 52).

\section{REFERENCES}

Baias, S., Blaga, L., Dehoorne, O., Grama, V., Gozner, M., Herman, G. V., Ilieş, D. C., Ilieş, A., Josan, I., \& Morar C. (2010). Băile Felix-Băile 1 Mai-Betfia (judeţul Bihor), Harta geoturistică, [Geotourist map of the Băile Felix Băile 1 Mai - Befia Area (Bihor County], Editura Universităţii din Oradea.

Bailly, A. \& Béguin, H. (1982). Introduction á la Géographie Humaine. Masson, Collection Geographie, Paris.

Bailly, A. \& Béguin, H. (2001). Introduction á la Geographie Humaine. Armand Colin, Paris.

Bailly, A. (1991). Les concepts de la Géographie Humaine. Masson, Paris.

Bailly, A., Béguin, H. \& Scariati, R. (2017). Introducere în Geografia Umană [Introduction in Human Geography], Editura Universităţii „Al. I. Cuza” Iaşi.

Barnes, T.J. (2009). Economic Geography, in International Encyclopedia of Human Geography, edited by R. Kitchin and N. Thrift, 315-327.

Carles, C.V. (1998). Geografia Humana, Universidad de Barcelona.

Ciangă, N., Tofan, G. B., Niţă, A., Păcurar, B. N. (2018), The Occupational Structure of Romania, Transylvanian Review, 27 Supplement (2): 301-316.

Claval, P. (1974). Elements de Geographie Humaine. M-th. Gemin, Libres Techiques, Paris.

Cocean, P., Niță, A., \& Dombay, Șt. (2013) Județele României. Județul Harghita [Counties of Romania. Harghita County], Editura Academiei Române, Bucureşti.

Harries, K.D., \& Norris, R.E. (1986). Human Geography. Culture, Interaction and Economy. Merrill Publishing Company, Columbus. Ohio.

Herman, G. V., \& Benchiş, L. B. (2017). Fairs, forms of expression of the local identity. Case study: Beiuş fair, Bihor County, Romania. Analele Universităţii din Oradea, Seria Geografie, 27(1), 108-113.

Herman, G. V., Deac, A. L., Ciobotaru, A. M., Andronache, I. C., Loghin, V., ... \& Ilie, A. M. (2017). The role of tourism in local economy development. Bihor County Case Study. Urbanism. Architecture. Constructions / Urbanism. Arhitectura. Constructii, 8(3): 265-274.

Herman, G. V., Ilieș D.C., Baias Ș., Măduța M.F., Ilieș A., Wendt J., \& Josan I. (2016). The tourist map, scientific tool that supports the exploration of protected areas, Bihor County, Romania. GeoSport for Society, 4(1): 24-32.

Ilie A. M., Herman G.V., Ciobotaru A.-M., Grecu A., Radu R. A., Visan M. C., Giurgia M. (2017), The role of tourism in structural dynamics of the economic profile of Sighisoara City, Urbanism. Architecture. Constructions / Urbanism. Arhitectura. Constructii, 8(4): 377-386.

Ilieș, A., Wendt, J. A., Ilieș, D. C., Herman, G. V., Ilieș, M., \& Deac, A. L. (2016). The patrimony of wooden churches, built between 1531 and 2015, in the Land of Maramureș, Romania. Journal of Maps, 12(sup1), 597-602.

Max, D. (1991). Geographie humaine, Armand Colin, Paris.

Nimigeanu, V. (1996). România. Geografie Umană, [Romania. Human Geography], Editura Universităţii „Al. I. Cuza”, Iaşi.

Păcurar, Al. (2006). Geografie economică mondială [World Economic Geography], Editura Presa Universitară Clujeană, Cluj Napoca.

Pop, P. Gr. (1972). România. Geografie Economică [Romania. Economic Geography], Partea I, Institutul Pedagogic din Oradea, Facultatea de Istorie-Geografie, Oradea.

Pop, P. Gr. (1996). România. Geografie Hidroenergetică [Romania. Hydroenergetic Geography], Editura Presa Universitară Clujeană, Cluj-Napoca.

Pop, P. Gr. (2012a). Depresiunea Transilvaniei [Transylvania Depression], Editura Presa Universitară Clujeană, Cluj-Napoca. Pop, P. Gr. (2012b). The Industry of Someşul Mic Corridor, 2012, Studia UBB, Geographia, LVII, (2): 133-144.

Pop, P. Gr., (2007). Județele României. Judeţul Cluj [Counties of Romania. Cluj County], Editura Academiei Române, Bucureşti.

Pop, P. Gr., Mîrza, A. (2012). Industrial Park of Someşul Mic Corridor, 2012, Studia UBB, Geographia, LVII, (1): 53-64.

Romocea, T., Oneț, A., Sabău, N.C., Oneț, C., Herman, G.V., \& Pantea, E. (2018), Change of the groundwater quality from industrial area Oradea, Romania, using Geographic Information Systems (GIS). Environmental Engineering \& Management Journal (EEMJ), 17(9): 2189-2199.

Șoneriu, I., Mac, I. (1973). Județul Mureș [Mureș County], Editura Academiei R.S. R., Bucureşti.

Tofan, G. B. (2014). Defileul Mureșului. Studiu de Geografie Umană [Mureș Defile. Human Geograhy Study], Editura Presa Universitară Clujeană, Cluj-Napoca. 
Tofan, G. B., Niţă, A. (2018). Industrial activities in Mureș County, 2018, Analele Universităşii din Oradea, Seria Geografie, 28 (2): 36-53.

*** (1984). Geografia României, II, Geografia Umană şi Economică [Romanian Geography, II. Human Geography and Economic], Editura Academiei R. S. R., Bucureşti.

*** (2011). România în cifre. Breviar statisticm Institutul Naţional de Statistică, Bucureşti.

http://www.mures.insse.ro, accesed: $12^{\text {th }}$ June 2017.

http://www.cciams.ro/topul_firmelor/index.html,accesed: $12^{\text {th }}$ June 2017.

http://www.zi-de-zi.ro/, accesed: 12 $2^{\text {th }}$ June 2017.

Submitted:

Octomber 10, 2018
Revised:

December 10, 2018
Accepted and published online February 18, 2019 